\title{
Internalisasi Nilai Kearifan Lokal Dalam Kegiatan Pengabdian Masyarakat oleh Perguruan Tinggi di Era Global
}

\author{
Dr. Adhi Nugraha, MA
}

\section{Kearifan lokal dilahirkan oleh budaya}

Kearifan lokal, demikian juga tradisi, adalah produk hasil budaya. Oleh sebab itu, sebagaimana halnya budaya, kearifan lokal dapat dibagi menjadi dua: pertama, kearifan lokal yang bersifat kebendaan (material, tangible), dan kedua, kearifan lokal bukan benda (intangible). Lingkup kearifan lokal kebendaan bisa diurai lagi menjadi komponen yang lebih spesifik, seperti kearifan dalam penggunaan material, penciptaan perabotan-peralatan utilitas, arsitektur dan artefak lainnya, hingga kreasi bentuk, ornamentasi atau ragam hias. Dalam hal penggunaan material dan peralatan, banyak kearifan kita temui dalam penggunaan, pengolahan, dan pengelolaan sumber daya alam sebagai bahan baku pembuatan artefak, makanan, maupun obat-obatan tradisional. Adapun kearifan lokal bukan benda, adalah semua aktivitas manusia yang berupa cara/pandangan hidup, adat istiadat, maupun tingkah laku manusia seharihari. Kedua jenis kearifan lokal ini dilahirkan, dibentuk. dan dikembangkan oleh budaya. Setiap masyarakat lokal tertentu akan menciptakan kearifan lokal tertentu yang dipengaruhi oleh budaya, kondisi geografis setempat, dan beberapa faktor eksternal (Joedawinata, 2005).

\section{Apa yang menarik dari kearifan lokal?}

Dalam berbagai artefak dan praktek budaya yang banyak berisi kearifan lokal di dalamnya, kita sering temukan prinsip-prinsip keseimbangan yang harmonis antara fungsi dan estetik, antara aspek fisik dan ideologi, antara keputusan ekonomi dan ekologi, yang merupakan hasil dari akumulasi ribuan tahun kebijaksanaan kolektif dan pengalaman praktis (Nugraha, 2012). Berbagai macam kearifan lokal yang meliputi pengetahuan, praktek, dan metoda yang diterapkan oleh masyarakat indigenous sering terbukti memiliki kelebihan-kelebihan unggul untuk keberlangsungan kehidupan masyarakat (sustainability), dilihat dari kemampuan dan pengetahuan empirik mereka akan ekosistem lokal. (Howes, 1980). Sejumlah riset juga telah mengungkapkan, mayoritas dari berbagai praktek indigenous cenderung selaras dengan hukum alam (natural law). Budaya yang masih bergantung secara langsung pada berburu, atau menangkap ikan, lebih memiliki prilaku memelihara baik produk maupun sumber daya alam. Sebagai contoh, adalah tabu membunuh binatang lebih dari yang diperlukan, atau menyia-siakan / membuang bagian dari binatang buruan (Benyus, 2002). Beberapa contoh tersebut bisa dijadikan pijakan dalam merumuskan peran dan pengembangan kembali kearifan lokal bagi peradaban manusia masa kini.

\section{Faktor-faktor mengapa isu kearifan lokal menjadi penting}


1. Berkembangnya keprihatinan akan kehilangan kearifan lokal berupa pengetahuan-pengetahuan berharga dari masa lalu. Mayoritas dari pengetahuan, cara dan metoda tradisional dikuasai oleh individu-individu sebagai 'tacit knowledge'. Jika individu/orang trampil ini luput menurunkan ilmu mereka ke orang lain, maka ilmu/ketrampilan itu akan musnah. Untuk menemukan kembali pengetahuan kearifan lokal yang hilang tersebut sangat berat, mahal, dan memakan waktu yang panjang. (Dormer, 1997).

2. Budaya, tradisi, termasuk di dalamnya berbagai kearifan lokal, telah menjadi alat banyak negara untuk membangun identitas nasional, sebagai 'budaya tandingan' untuk melawan 'dominant culture' atau globalisasi. Memberikan tradisi sebuah nafas/kehidupan baru sering menjadi target nasional. Saat ini, di masyarakat lokal di mana pun, ada kebutuhan kuat untuk memunculkan identitas kelokalannya sendiri. (Alver, 1992)

3. Faktor paling kuat mengapa kita perlu melestarikan dan mengembangkan berbagai tradisi dan kearifan lokal adalah banyak dari artefak/ pengetahuan/metoda/cara tradisional yang berfungsi harmonis, selaras dengan hukum-hukum alam. Menggabungkan kearifan lokal dengan kondisi ilmu pengetahuan dan teknologi saat ini merupakan salah satu langkah bijaksana dalam rencana besar revitalisasi tradisi dan budaya, di mana keberlangsungan (sustainability) telah menjadi isu utamanya.

\section{Era Global}

Era global atau disebut sebagai globalisasi dimaknai sebagai mulainya masa peradaban manusia yang ditandai oleh perkembangan dan kemajuan ilmu pengetahuan, teknologi dan mobilitas manusia yang sangat pesat. Di bidang ilmu pengetahuan dan teknologi ditunjukkan dengan terjadinya revolusi teknologi informasi, teknologi komunikasi, dan teknologi industri. Bioteknologi, nano teknologi, internet, artificial intelligent (AI), dan sistem fisik siber (CPS) adalah beberapa bidang yang berkembang terus dengan pesat dan kita belum paham di mana dan bagaimana bidang ini mencapai puncaknya. Saat ini, ketika kita digiring untuk mulai mengadopsi era Industri 4.0 yang sudah melanda dunia, segala aspek kehidupan kita didorong untuk menyesuaikan diri terhadap tuntutan-tuntutan baru, terutama pada perubahan cara kerja, teknologi, dan pengelolaan yang bersifat digital. Era global saat ini juga ditandai dengan pergerakan manusia yang menjadi sangat cepat dan tanpa batas, baik secara geografis/negara, maupun budaya. Ketika interaksi antar budaya dan tradisi semakin mudah dan lebih sering terjadi, hal ini akan terus memicu munculnya pertukaran budaya yang bebas tanpa batas antar suku dan antar bangsa. Sebagai konsekuensinya, konsep tentang budaya pun mengalami perubahan; budaya tidak lagi dipandang sebagai suatu sistem yang tertutup, solid dengan segala keunikan dan esensi khasnya, tetapi di era global ini budaya sebenarnya lebih mencerminkan karakteristik yang dinamis, fluid, mengalir dan terus mengalami bentukan-bentukan baru tanpa henti (Sugiharto, 2019).

Secara umum, era global ini memiliki dua sisi; ada dampak positif dan juga negatif yang dihasilkannya. Sisi positif yang dapat dicatat adalah terjadinya pertukaran dan perkembangan ilmu pengetahuan, teknologi, seni dan budaya secara cepat akibat kemudahan akses dan sirkulasi informasi. Hal ini 
merangsang tumbuhnya inovasi-inovasi baru di segala bidang dan keterbukaan di segala aspek, misalnya lingkungan, politik, sosial, pemerintahan, informasi, dan ekonomi. Berbagai sisi positif ini jelas berkontribusi terhadap peningkatan kualitas kehidupan masyarakat secara luas. Bagaimanapun, era global memiliki sisi gelap juga, di antaranya adalah terkait isu kerusakan lingkungan berupa polusi air dan udara, masalah sampah, eksploitasi sumbardaya alam di darat dan lautan, pemanasan global, konsumerisme, homogenisasi budaya, dan penurunan nilai-nilai penting kehidupan (Papanek 1985, Zaccai 1995). Dampak negatif dari produk-produk, limbah, dan gaya hidup telah menjadi masalah yang berkembang, memaksa kita belajar dari kearifan lokal dan penggalian kembali pengetahuan tradisional. Tradisi 'techne' bukanlah suatu pengharapan romantis, tetapi benar-benar sebuah tindakan praktis dalam kerangka logika total ekonomi. (Fry, 1994).

Pergerakan era global yang membawa dampak negatif perlu disikapi dengan bijaksana. Homogenisasi produk dan budaya telah menimbulkan penyakit sosial (social illness), salah satunya pengikisan jati diri, lokalitas, dan keragaman (Ihatsu, 2002). Di samping itu, percepatan yang terjadi di berbagai aspek kehidupan manusia yang dihasilkan oleh era global saat ini tidak selalu menghasilkan kebaikan bagi kehidupan. Manusia moderen saat ini perlu kembali menarik pelajaran dari alam, seperti yang banyak dilakukan oleh masyarakat tradisional sebelumnya. Alam tumbuh dan berkembang dalam keadaan tidak pernah terburu-buru untuk menghasilkan beragam karya yang sering menakjubkan dengan cara berkelanjutan. Hal penting lainnya yang alam ajarkan kepada umat manusia adalah di alam (nature), sebagai hukum, tidak ada istilah sampah, dan setiap unsur hanya menggunakan energi yang diperlukan (Benyus, 2002).

\section{Strategi}

Secara filosofis strategi internalisasi kegiatan pengabdian kepada masyarakat terkait isu kearifan lokal adalah bagaimana masyarakat bisa mengadopsi sisi baik yang disuguhkan oleh globalisasi dan menghindari sebanyak mungkin dampak negatifnya. Berbagai kritik terhadap globalisasi bisa dijadikan sebuah acuan dan basis yang relevan bagi pengambilan keputusan dalam memposisikan peran kearifan lokal dan budaya secara luas. Peradaban manusia tidak bisa mengambil jalan mundur ke belakang, melainkan mencoba membuat kompromi dan penyesuaian-penyesuaian. Langkah kongkret untuk merealisasikan gagasan ini bisa bertumpu pada konsep Revitalisasi Tradisi. Ide utama dari revitalisasi tradisi adalah bagaimana suatu tradisi yang berisi kearifan lokal ditransformasikan ke dalam bentuknya yang baru dengan cara mengawinkannya dengan elemen-elemen kekinian yang berwujud sebagai ilmu pengetahuan, teknologi, cara pandang dan aspek kehidupan lainnya pada masa kini. Pengembangan kearifan lokal sejatinya dapat memberikan benefit bagi kehidupan masyarakat masa kini dan yang akan datang secara berkeberlangsungan. Hasilnya dapat berupa pelestarian, pengayaan dan pengembangan budaya yang berbasis pada aplikasi teknologi tepat guna yang memanfaatkan berbagai sumberdaya lokal. McDonough dan Braungart dalam bukunya Cradle to Cradle menegaskan bahwa "all sustainability is local". Untuk terus menjaga keberlangsungan, sistem manusia dan industri harus terhubungkan dengan aliran material dan energi lokal -dengan kekuatan-kekuatan sosial, budaya dan ekonomi lokal -hingga 
beragam kebiasaan, kebutuhan, dan selera lokal, dari level wilayah itu sendiri (McDonough dan Braungart, 2002).

\section{Penutup}

Kearifan lokal bagi sebuah bangsa dan negara adalah warisan kekayaan yang sangat berharga, sebagai bentuk ilmu pengetahuan yang secara empirik mengalami proses pemutakhiran lintas generasi dari masa ke masa yang disesuaikan dengan situasi, kondisi lingkungan, cara pandang, dan kebutuhan masyarakat lokal. Internalisasi nilai kearifan lokal dapat efektif berjalan dengan cara merevitalisasi berbagai bentuk kearifan lokal yang akan menempatkan karakteristik, jati diri, identitas, nilai-nilai kelokalan kembali pada fungsi dan peran terbaiknya di masyarakat. Mentransformasikan kearifan lokal berarti mengawinkannya dengan kondisi terkini dari IPTEKS untuk mendapatkan bentuk barunya yang aplikatif dan sesuai dengan kehidupan masyarakat masa kini melalui kegiatan penelitian, pengembangan, dan edukasi. Cara ini bisa berarti bagaimana menciptakan perpaduan yang harmonis antara teknologi digital dengan kearifan lokal tertentu, atau bagaimana menggabungkan ketrampilan tradisional tertentu dengan peralatan moderen. Kegiatan pengabdian kepada masyarakat perlu menciptakan ekosistem yang dapat mewujudkan minat dan potensi masyarakat untuk menggali kembali dan mengembangkan kearifan lokal yang mereka miliki dengan cara memotivasi dan memberikan penyadaran akan potensi mereka sendiri.

\section{Referensi}

Alver, B. (1992) 'The Making of Traditions and the Problem of Revitalization' in Kvideland, R. (Ed.), Tradition and Modernization, 66-69, Turku: Nordic Institute of Folklore.

Benyus, J. M. (2002) Biomimicry: Innovation Inspired by Nature, New York: Harper Collins Publishers Inc.

Dormer, P. (1994) The Art of the Maker: Skill and Its Meaning in Art, Craft, and Design, London: Thames and Hudson Ltd.

Fry, T. (1994), Re-makings: Ecology, Design, Philosophy, Sydney, Envirobook.

Joedawinata, A. (2005),Unsur-unsur Pemandu dan Kontribusinya Dalam Perwujudan Sosok Artefak Tradisional Dengan Indikasi-indikasi Lokal yang Dikandung dan Dipancarkannya, Doktoral disertasi, Bandung, Institut Teknologi Bandung.

Ihatsu, A. M. (2002), Making Sense of Contemporary American Craft, Doktoral Disertasi, Publications in Education no. 73, Joensuu, University of Joensuu.

McDonough, W., Braungart, M. (2002), Cradle to Cradle: Remaking the Way We Make Things, New York, North Point Press.

Nugraha, A. (2012), Transforming Tradition: A Method for Maintaining Tradition in a Craft and Design Context, Helsinki, Aalto University Press. 
Sugiharto, B. (2019) Kebudayaan dan Kondisi Post-Tradisi: Kajian Filosofis Atas Permasalahan Budaya Abad ke-21, Yogyakarta, PT Kanisius.

Walker, S., Evans, M., Cassidy, T., Jung, J., Twigger Holroyd, A.(2018), Design Roots: Culturally Significant Designs, Products, and Practices, London, Bloomsbury Academic. 